Eighth ERES Conference,

Glasgow, 4-7 June 2002

\title{
The Use of MIS Systems for Corporate Real Estate Asset Management
}

\author{
John McDonagh, Senior Lecturer Property Group, Lincoln University, New Zealand.
}

Key Words corporate, real estate, asset management, property, performance, measurement, management information systems, survey, New Zealand

\begin{abstract}
Prior research has identified that one of the significant factors associated with higher levels of performance in the management of corporate real estate assets is the existence and use of computerised corporate real estate management information systems (CRE MIS). This paper reports the results of a survey of 457 organizations in New Zealand with significant corporate real estate portfolios. It includes details on the existence of and assessed performance of the CRE MIS as a whole, as well as the importance of various data sub-components. Results include a minority but significant percentage of organizations still lacking CRE MIS, or rating their use as unimportant. Few organizations with CRE MIS rate their performance as excellent. Correlational analysis was also carried out to determine if significant associations could be observed between CRE MIS performance and other organizational characteristics. Findings include significant differences in the ways organizations use their CRE MIS but a high degree of correlation between the performance of CRE MIS and other measures of corporate real estate asset management (CREAM) performance.
\end{abstract}

\section{Introduction}

Over the last ten years, the contribution effective corporate real estate asset management can make to an organizations core business activity has come in for increased attention. In order to learn from organizations that have made progress in this area it is necessary to examine in detail those aspects of management that contribute to an enhanced level of performance.

As differently structured and focused organizations require different things from their real estate assets, (for example: marketing profile, low cost, distribution efficiency, employee retention or proximity to markets or resources,) there is no easily identified “output” indicator of "good” performance. As a result previous performance research has focused on inputs to, and the process of, corporate real estate decisionmaking (Gibson 1995a). 
One such input factor identified by previous research is the quantity and quality of information available to management to support decision-making. For large corporate portfolios such information is usually reflective of the existence and quality of corporate real estate management information systems (CRE MIS) within the organisation.

This research reports on the state of CRE MIS within a wide range of organisations in New Zealand. It also examines relationships between various CRE MIS characteristics and organisational factors.

\section{Literature Review}

While corporate real estate research is relatively limited, previous studies frequently refer to the importance of CRE MIS.

Zeckhauser and Silverman (1983) stated that prudent decision-making requires monitoring data and that it is extremely difficult, if not impossible, to make informed real estate decisions without an independent real property MIS.

One of the key recommendations of the RICS (1987) to an Audit Commission (UK) study of the property management practices of local authorities was: “A central comprehensive property database utilizing standardized definitions and methods of measurement is essential. A split between operational property and non-operational property is desirable”.

The UK National Audit Office (Bourne 1988) report on the National Health Service sought to determine, amongst other things, if a reliable property database had been set up. It was found that in the $20 \%$ of NHS districts that had collected reasonably complete data, $40 \%$ of current land holdings were surplus. The one authority that had made substantial progress with their database had also made substantial capital and revenue savings.

Two of the seven “dimensions of performance” identified by Veale $(1988,1989)$ were:

- the use of management information systems for real estate operations,

- availability of information and methods for evaluating real estate performance and use.

Veale found that many of the corporations he surveyed were unsure of the area they owned (19\%) or leased (24\%). One in four did not maintain a property inventory of any kind and 66\% had inadequate information available for ongoing management of their real estate assets. 
In a similar survey of corporate real estate (CRE) executives Pittman and Parker (1989) found that a comprehensive computerized corporate real estate inventory was a significant factor in corporate real estate asset management (CREAM) performance.

Gale and Case (1989) found 90\% of organisations had some form of real estate record but often this was historic, maintained by the accounting department and not readily available or suitable for effective decision-making.

Avis, Gibson and Watts (1989), found that organisations may hold basic property data but this was often incomplete, inaccurate and not held in a CRE MIS that made it readily retrievable. Furthermore, the minority of organisations that did have CRE MIS were less than satisfied with its performance.

The National Audit Office (Bourne 1989) investigated the "Control and Management of the Metropolitan Police Estate". One of the findings was that a prerequisite to improved strategic planning was more accurate information on the whole of the police estate, to allow the effectiveness of decisions to be assessed. " A full property database should be developed urgently which would help bring about a more cohesive system of financial planning" (p.5).

In an analysis of 231 universities by Silverman (1990) it was found that management was "accounting rather than accountability”(p.5). Silverman advocated the application of pro-active asset management techniques derived from the business sector, which included setting up an inventory of physical assets and the use of ongoing and transparent means of performance evaluation.

The only earlier CRE research of significance in New Zealand,by Teoh (1992), found only 39\% of respondents maintained a real estate inventory of any kind, and 7.3\% a separate CRE MIS.

Simons (1993) examined local authority CREAM and compared Cleveland, Ohio with the Swedish situation as reported by Lundstrom (1991). Again the fundamental issues of real estate inventories and information systems, property by property accounting and performance monitoring were identified. In a survey of fifty large publicly listed companies in the USA, Apgar (1993) found 66 percent of the respondents were unable to respond to the questionnaire as they did not have sufficient data on their corporate real estate assets.

Redman, Johnson and Tanner (1994) surveyed 986 members of NACORE and found while 96\% of respondents had lease documents pertaining to their properties, only 34\% had information on current market rents payable on similar properties. Other characteristics of CRE MIS were examined in detail and it was concluded that historic accounting information dominates current systems, with relatively little data 
that would aid future decision-making. The report points out that while useful new techniques are being developed by academics, they often assume corporates already have, or can obtain, the basic input data needed, but this is often not the case.

Nourse (1994) confirmed earlier findings that creating a separate CRE MIS is associated with a tighter linkage between CRE operations and CRE strategy. He also found it facilitated better communications amongst operational, financial and CRE management personnel.

Collecting information for control and decision making, and subsequently monitoring progress towards achieving objectives are measures of CREAM performance discussed by Gibson (1991). In a further paper by Gibson (1994) she identifies a consistent picture of process weaknesses across a wide range of organizations, one component of which is inadequate information for valid and transparent decisionmaking. As a result she includes adequate property, operational and external information as key components in her "Strategic Framework" for the management of corporate real estate assets.

A local authority context was the focus for French (1994) and an asset register was identified as a primary requirement. He also highlighted the importance of systems to monitor the ongoing performance of the property portfolio in meeting the organization's goals. The management issues involved in addressing deficiencies in local authority asset registers were also discussed, as were the problems when established valuation protocols led to recording property values on a basis that was meaningless from a performance monitoring viewpoint.

Byrne (1994) highlighted the positive effects on CRE MIS of the restructuring of local government in England. The major transfers of assets between local authorities made the establishment of an accurate property a priority. For many local authorities this highlighted for the first time, the relative importance of property assets. In other cases the information was recorded, but in incompatible forms held by diverse agencies and often compiled for central government treasury use rather than in a format useful for strategic property management.

Johnson, Redman and Tanner (1997) surveyed 986 organisations and concluded that computing systems for CRE have tracked the development of other business computing applications, but are still focused on historic and accounting data rather than decision support. What decision support does exist is usually generated on spreadsheets. They also identified superior rates of CRE MIS performance amongst large companies and banking and finance organisations. The latter was put down to the greater familiarity these types of organisations may have with property data due to the nature of their core business. 


\section{Research Methodology}

The aim of this research was to examine the current state of CRE MIS amongst New Zealand organizations and, in addition, to see if significant associations could be identified between CRE MIS characteristics and other organizational factors.

The data source was a mail survey of 457 corporate real estate executives from a wide range of commercial and non-profit organizations in New Zealand. These included: all government departments, state -owned enterprises, energy companies and territorial local authorities; all the non-investment companies listed on the New Zealand stock exchange; plus the largest privately owned companies as identified in the government publication “New Zealand's Top 200 Companies”. Finally, all major churches and registered charities were included.

The survey questionnaire was quite comprehensive as the data collected was to be used for a number of purposes in addition to the subject of this paper. The specific questions relating to CRE MIS were labelled I1a to I2k and worded as follows:

\section{Information Systems}

I 1. With respect to having access to an accurate computerised database containing details on each property, would you please Firstly circle the importance of a database to your organisation and Secondly circle the performance of your organisation's database on the scale below. Circle N/A if you have no database.

\begin{tabular}{|c|c|c|c|c|c|c|c|}
\hline not important & & 1 & 2 & 3 & 4 & 5 & extremely important \\
\hline poor performance & N/A & 1 & 2 & 3 & 4 & 5 & excellent performance \\
\hline
\end{tabular}

I 2. If your organisation has a computerised property database circle its performance on each of the following:

Shows adequate details on:

a - Current use of property

b - Physical attributes - ie. size, dimensions, age etc

c - Legal matters including zoning, tenure etc

d - Lease details if applicable

e - Purchase cost

f - Current market value

g - Operating/maintenance costs

h - Maintenance programme

i - No. of people working within specific buildings

$\mathrm{j}$ - Usefulness in assisting in strategic decisionmaking

$\mathrm{k}$ - Usefulness in identifying non-performing properties

$\begin{array}{crrrr}\text { Poor } & & \text { OK } & & \text { Excellent } \\ 1 & 2 & 3 & 4 & 5 \\ 1 & 2 & 3 & 4 & 5 \\ 1 & 2 & 3 & 4 & 5 \\ 1 & 2 & 3 & 4 & 5 \\ 1 & 2 & 3 & 4 & 5 \\ 1 & 2 & 3 & 4 & 5 \\ 1 & 2 & 3 & 4 & 5 \\ 1 & 2 & 3 & 4 & 5 \\ 1 & 2 & 3 & 4 & 5 \\ 1 & 2 & 3 & 4 & 5 \\ 1 & 2 & 3 & 4 & 5\end{array}$


The response rate of $42 \%$ was high compared to similar studies. Characteristics of the respondents are summarised in Figures 1-3 below. Analysis of non-respondents indicated the results should be representative.

Data from the survey forms were checked for errors, edited, coded and entered into the SPSS software package for analysis. The statistical tests used to examine associations between the CRE MIS responses and responses to other questions in the survey ${ }^{1}$ were as follows:

- For combinations of two binary variables - Chi squared

- For combinations of binary with ordinal variables - Mann Whitney U - Wilcoxon Rank Sum W

- For combinations of two ordinal variables - Spearman Correlation Co-efficients

- For combinations of ordinal and continuous variables - Spearman Correlation Co-efficients

\section{Results}

\section{Characteristics of the Respondent Organisations}

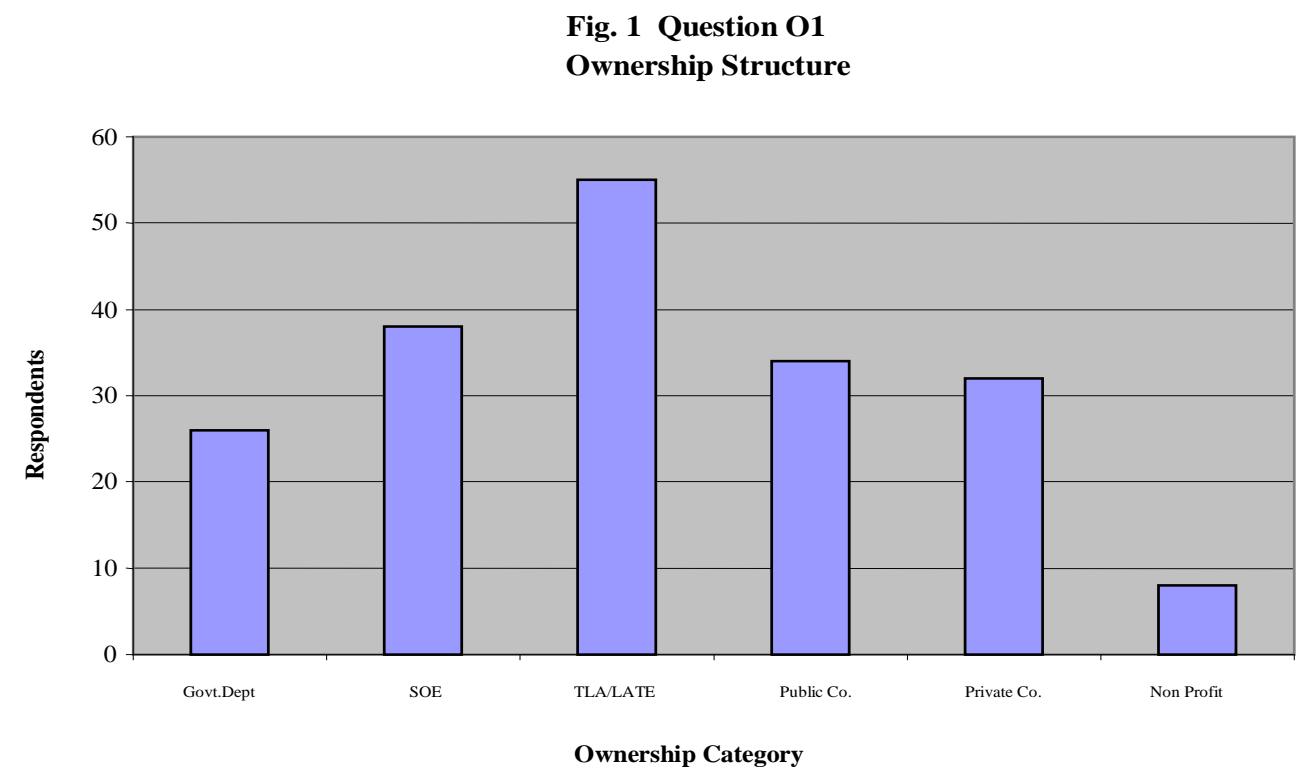

As shown in Figure 1, the distribution of ownership structures amongst respondents was reasonably even except for a lower representation of private companies. The latter may have been due to a number of private companies being wholly owned subsidiaries of listed companies with their CREAM carried out by

\footnotetext{
${ }^{1}$ The complete survey questionnaire is available from the author.
} 
the parent body. There may also have been a lack of interest in the surveyed issues by smaller companies with relatively minor property portfolios.

\section{Core Business}

Respondent organisations were individually allocated to one of 13 business categories based on the New Zealand Standard Industrial Classification primary codes. Again it can be seen in Figure 2 that the distribution of responses was relatively even, except for the over representation of Territorial Local Authorities (TLA's).

Fig. 2 Question 02

\section{Organisation Core Business}

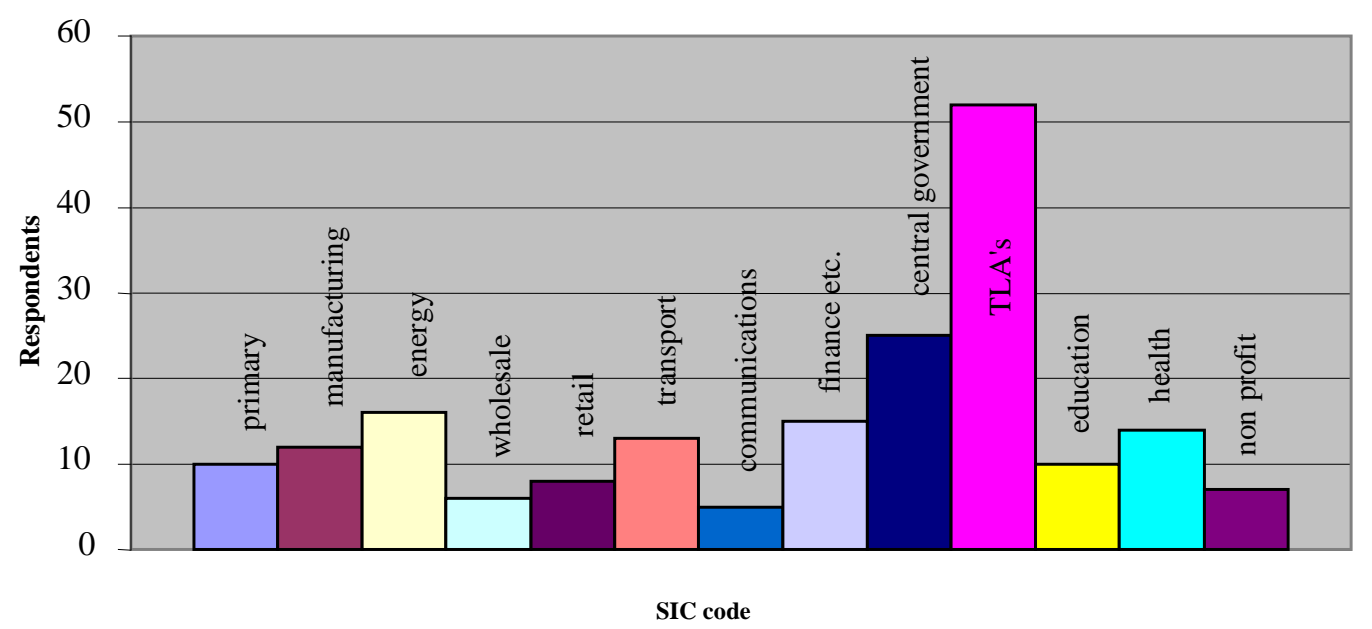

\section{Employee Numbers}

Most of the organizations responding were large in terms of typical New Zealand businesses, with over 50\% having more than 200 employees and 32\% more than 500.

Fig. 3 Question 03

Employee Numbers

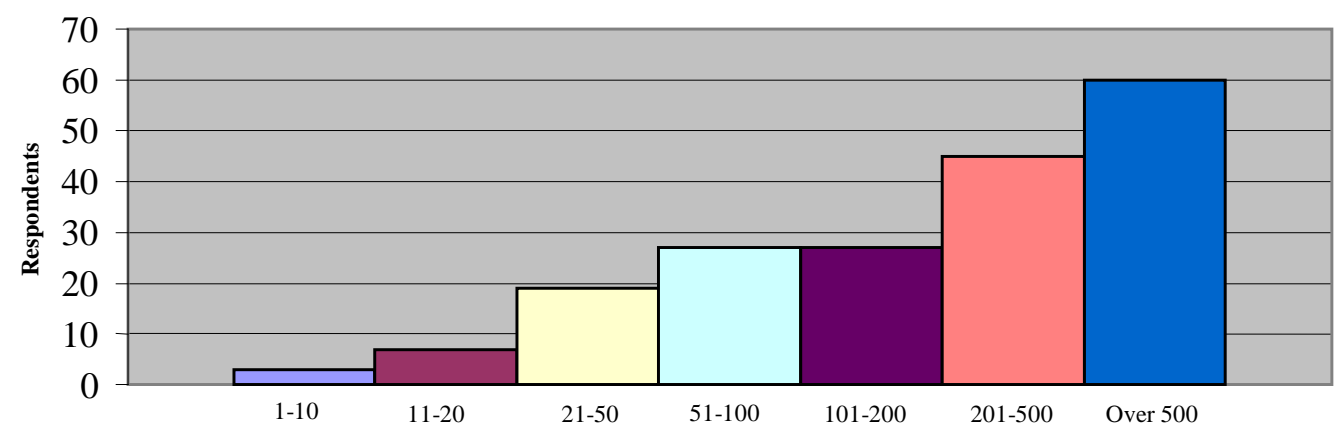




\section{Characteristics of the Respondent's Property Portfolios}

\section{Number of Freehold Properties Owned}

As shown in Figure 4, the largest category was organizations with more than 100 freehold properties, again indicating responding organizations were large in terms of typical New Zealand businesses.

Fig. 4 Question P1

Number of Properties Owned Freehold

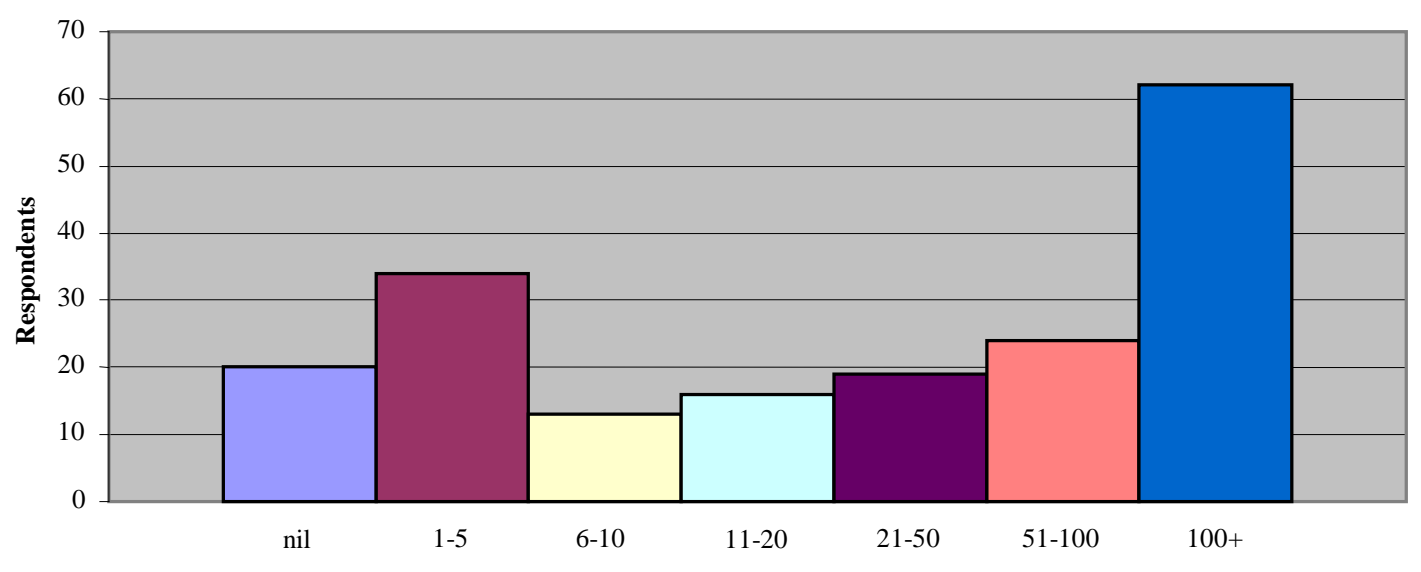

However, the second largest category was at the opposite end of the scale (1-5 freehold properties), and there were a significant number of organizations with no freehold properties at all. As this distribution was not reflected in the question on the number of employees it emphasises that many New Zealand organizations choose to lease property, irrespective of their relative size in terms of employee numbers.

\section{Value of Freehold Properties Owned}

As expected given the results from the previous question, $11 \%$ had a nil return for freehold ownership, and there was a relatively small number of low value portfolios and a large number of high value portfolios as shown in Figure 5. 
Fig. 5 Question P2

Value of Properties Owned Freehold

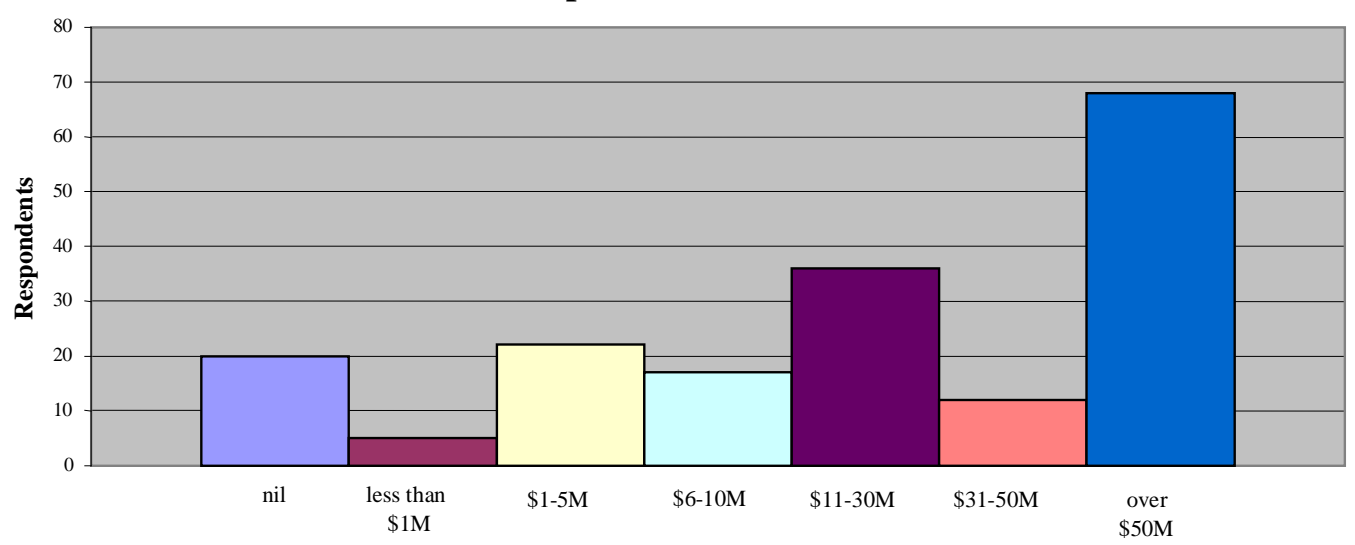

\section{Number of Properties Leased}

The results on leasing (Figure 6) were relatively even across all categories except for a relatively small number (5\%) who do not lease at all and a large number (34\%) who lease from 1-5 properties. As this latter category was also well represented in the freehold ownership question it may indicate that organizations tend to fall into one of two categories - those with a relatively large number of freehold properties, or alternatively those with a relatively small number of properties more evenly distributed between leasehold and freehold tenure.

Fig. 6 Question P3

Number of Properties Leased

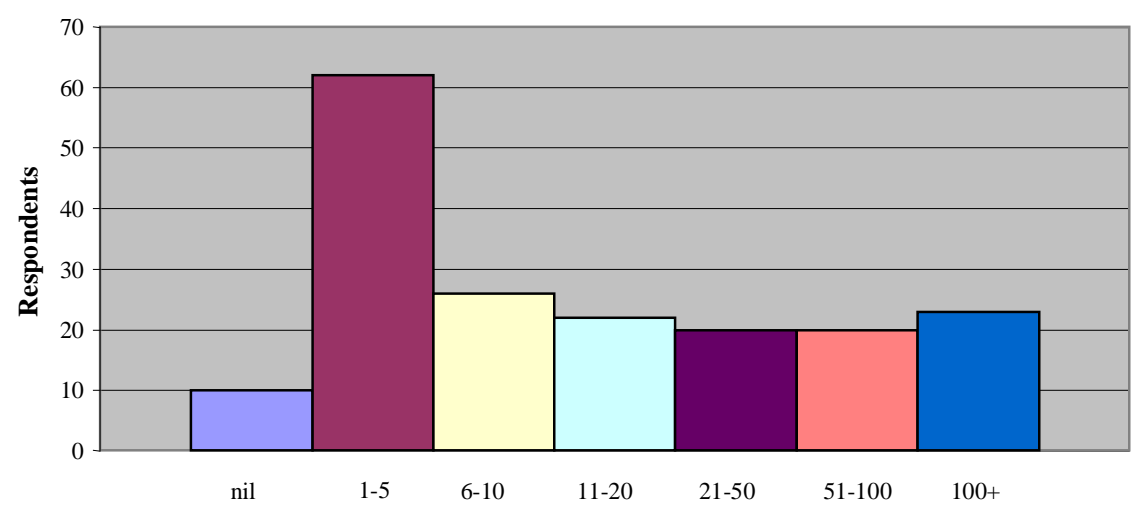




\section{Respondent rating of CRE MIS Importance and Performance}

Question I1a of the survey asked for a rating of the importance of an accurate and computerised MIS on a five-point scale. Similarly, question I1b asked respondents to rate the performance of their existing MIS on a five-point scale. The results of both questions are shown in Figure 7.

Surprisingly, 10\% rated having a good MIS as unimportant, but the majority reflected prior research and rated the importance of accurate information highly. The "not important" responses to this question may be uninformed responses because respondents did not have an adequate CRE MIS, reflected by the $28 \%$ not applicable response to question I1b. This latter rate is, however, a marked improvement on the earlier research of Teoh (1992), which found only 7\% of organizations had a CRE MIS of any description and 39\% had no real estate inventory at all.

Fig. 7 Questions I1a and I1b Overall CRE MIS System Performance

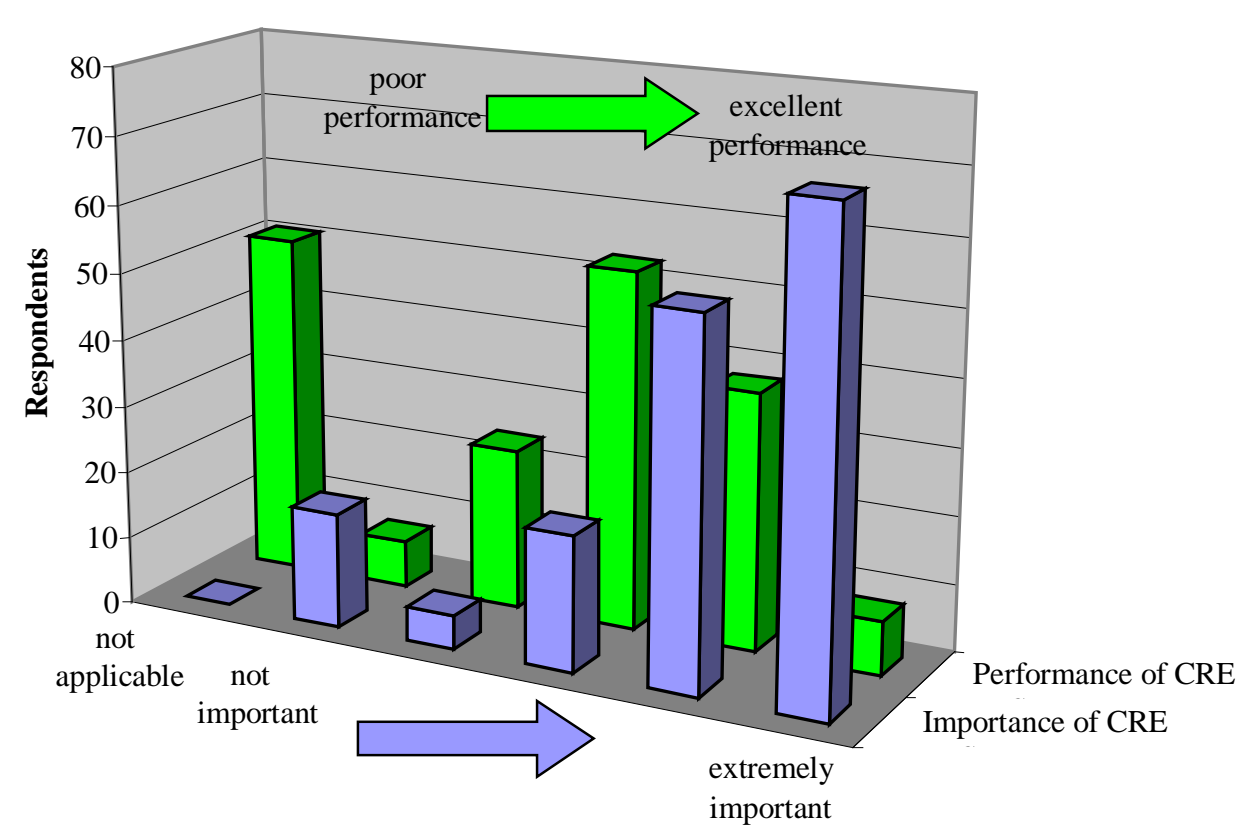

From the response to I1 b, many CRE MIS users were not happy with the performance of their systems with only $4 \%$ rating their performance as excellent, and a total of $25 \%$ rating the performance as 1 (poor) or 2 out of 5 . 


\section{CRE MIS Performance in Dealing with Particular CRE Data}

Questions I2a-I2k asked respondents to use a five-point Likert scale to rate CRE MIS performance in respect of various data sub-components. The results are represented by bar length in Figure 8 .

Fig. 8 Questions I2a to I2k Performance of CRE MIS Functions

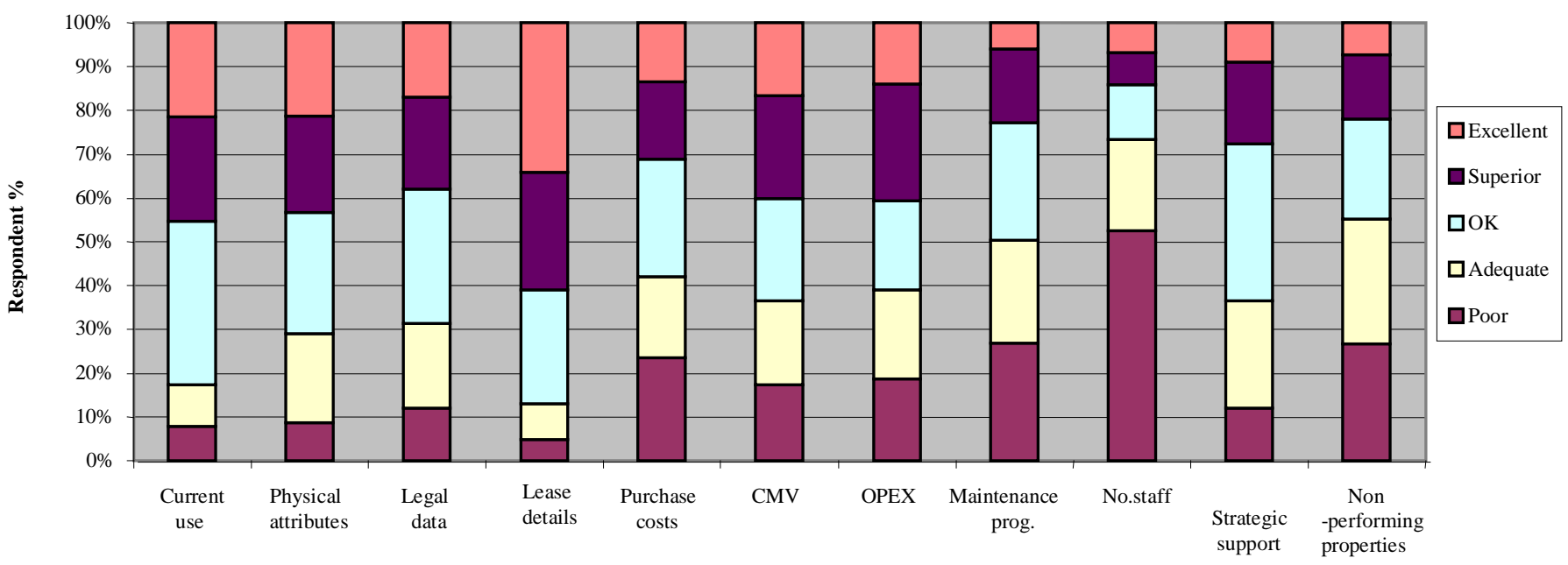

The areas of poorest performance were recording of the number of staff working within specific buildings, followed by the recording of maintenance programmes, identifying non-performing properties and recording purchase costs. The areas of best performance were in the recording of lease details, current use, physical attributes and legal data. This is unsurprising as these are the details needed for conventional investment property management and form the basis of many standard property management software packages. They may also represent accounting requirements.

\section{Correlations Amongst CRE MIS Questions I1a-I2k}

This test was to determine if respondents "holistic" assessment of overall CRE MIS performance as reported in question I1b was reflective of the MIS performance in respect of the various data subcomponents reported in questions I2a-I2k. Spearman Correlation Coefficients were applied and the results showed significant correlations ( $\mathrm{r}$ value range of 0.19 to 0.51 , $\mathrm{p}$ value range of 0.038 to $<0.000$ ) between answers on each of the individual data sub-components and Question I1b. As a result there was very high confidence that the rating for the overall performance of the organizations CRE MIS (question I1b) was fully representative of the data sub-components. 


\section{CRE MIS and Overall CREAM Performance}

Veale (1989) proposed that various factors/dimensions of CREAM performance (including the use of CRE MIS) are usually strongly correlated within individual organisations. This relationship was tested for in this research with the results shown in Table 1.

Table 1 Associations Between CREAM Performance Variables

\begin{tabular}{|c|c|c|c|c|c|c|c|}
\hline p values & $\begin{array}{l}\text { CRE unit } \\
\text { exists M1 }\end{array}$ & $\begin{array}{l}\text { Contributes } \\
\text { cashflow R5h }\end{array}$ & $\begin{array}{l}\text { Reporting level } \\
\text { C1\&C2a }\end{array}$ & $\begin{array}{l}\text { Strategic Plan } \\
\text { exists C3a }\end{array}$ & $\begin{array}{l}\text { Attitude to CRE } \\
\text { M8a }\end{array}$ & \multicolumn{2}{|c|}{$\begin{array}{l}\text { CRE MIS } \\
\text { performance I1b }\end{array}$} \\
\hline $\begin{array}{l}\text { CRE unit exists } \\
\text { M1 }\end{array}$ & $\#$ & & & & & & \\
\hline $\begin{array}{l}\text { Contributes } \\
\text { cashflow R5h }\end{array}$ & 0.002 & & & & & & \\
\hline $\begin{array}{l}\text { Reporting level } \\
\text { C1\&C2a }\end{array}$ & 0.000 & 0.70 & & & & & \\
\hline $\begin{array}{l}\text { Strategic Plan exists } \\
\text { C3a }\end{array}$ & 0.000 & 0.0 & 0.00 & \# & & & \\
\hline $\begin{array}{l}\text { Attitude to CRE } \\
\text { M8a }\end{array}$ & 0.000 & 0.0 & 0.56 & $0.0 c$ & \# & & \\
\hline $\begin{array}{l}\text { CRE MIS } \\
\text { performance I1b }\end{array}$ & 0.000 & 0.0( & 0.03 & 0.00 & 0.000 & & \\
\hline $\begin{array}{l}\text { Info/eval. methods } \\
\text { M8k }\end{array}$ & 0.631 & 0.95 & 0.31 & 0.38 & 0.005 & & 0.128 \\
\hline
\end{tabular}

Cells highlighted show relationships significant at the $5 \%$ level

As can be seen from Table 1 significant associations exist for combinations of all but the last of the following CREAM variables:

a Existence of a separate corporate real estate unit (question M1)

a Cash flow contribution by the corporate real estate unit (question R5h)

a Combined reporting level and frequency of liaison (question C1\&C2a)

- Existence of written CRE strategic plan (question C3a)

- CRE considered important to organization (question M8a)

- Availability of information and methods for evaluating CRE (question M8k)

Building on this relationship, a previous paper by the author (McDonagh, 2002) developed and tested an overall CREAM performance measure incorporating the above significantly correlated variables. The result was a factor score representing CREAM performance which applied to each organization in the survey.

As one of the five variables in this overall CREAM performance model is the performance of the CRE MIS, some correlation between overall CREAM performance and CRE MIS performance (as represented by question I1b) would be expected. However, it was still considered worthwhile to examine which individual data sub-components of CRE MIS were rated highly amongst those organizations who also had a high score in the overall CREAM performance model. The results of this analysis are presented in Table 2. 


\begin{tabular}{|lcc|}
\hline $\begin{array}{l}\text { Table } 2 \text { Associations Between CRE MIS Sub Data Components and Overall } \\
\text { CREAM Performance } \\
\text { (Spearman Correlation Coefficients used for all tests) }\end{array}$ & \\
\hline Question Number & r value & p value \\
I1a MIS system importance & 0.49 & $<0.000$ \\
I2a current use of property & 0.31 & 0.001 \\
I2b physical attributes - i.e. size, dimensions, age etc & 0.15 & 0.105 \\
I2c legal matters including zoning, tenure etc & 0.10 & 0.300 \\
I2d lease details if applicable & 0.20 & 0.036 \\
I2e purchase cost & 0.10 & 0.303 \\
I2f current market value & 0.24 & 0.014 \\
I2g operating/maintenance costs & 0.07 & 0.456 \\
I2h maintenance programme & 0.08 & 0.444 \\
I2i no. of people working within specific buildings & 0.02 & 0.825 \\
I2j usefulness in assisting in strategic decision-making & 0.33 & 0.001 \\
I2k usefulness in identifying non-performing properties & 0.33 & $<0.000$ \\
\hline
\end{tabular}

Cells highlighted show relationships significant at the $5 \%$ level

The highest correlations with overall CREAM performance were found for usefulness in identifying nonperforming properties and assisting strategic decision making, and showing details on current use of property, current market value and lease details. In contrast the lowest correlations were for showing the number of people working in buildings, operating and maintenance costs, purchase cost, legal details and physical attributes.

\section{CRE MIS and other Organizational Factors}

As well as the five variables included in the CREAM performance model above, a number of other organisational characteristics were found to be significantly associated with CRE MIS factors. These included the degree of both overall organisational restructuring $(\mathrm{p}=<0.000)$ and restructuring of the CRE unit $(p=0.029)$ and a high rating of the importance of CRE MIS. There were also significant differences between ownership structure $(p=0.004)$ and core business activity $(p=0.005)$ and the importance of CRE MIS.

While the number of staff in the whole organisation showed no relationship to the importance of CRE MIS, the number of staff in the CRE unit was highly significant (0.001) and positively correlated. In addition the property specific educational qualifications of the CRE executive completing the survey were 
positively associated with CRE MIS importance $(p=<0.000)$, CRE MIS performance ( $p=0.002)$, and several of the CRE MIS data sub-components.

An interesting further observation was the significant negative relationship between the number of employees engaged in corporate real estate work and the performance of the CRE MIS in the areas of recording real estate costs $(p=0.038)$, opex $(p=0.014)$ and maintenance $(p=0.002)$. It could be that improvement in CRE MIS performance facilitates a reduction in property staff either via efficiency or outsourcing.

The relationships between CRE MIS characteristics and decision-making techniques used are shown in Table 3. Significant associations exist for the use of DCF, risk diversification and relationship to CMV techniques.

\begin{tabular}{|c|c|c|c|c|c|c|c|}
\hline p values & 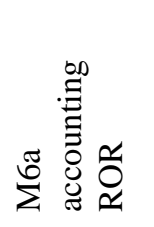 & 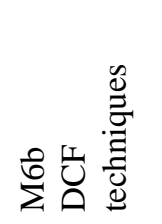 & 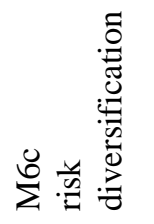 & 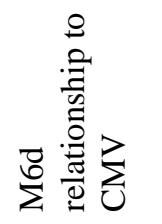 & 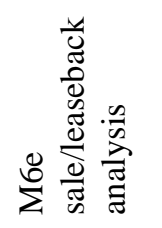 & 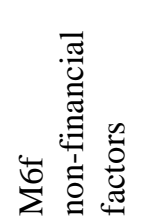 & 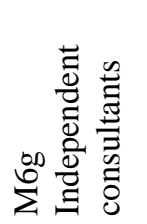 \\
\hline I1a MIS importance & 0.437 & 0.008 & 0.012 & 0.007 & 0.697 & 0.120 & 0.268 \\
\hline I1b MIS performance & 0.081 & 0.002 & 0.002 & 0.077 & 0.186 & 0.115 & 0.757 \\
\hline I2a current use & 0.019 & 0.006 & 0.062 & 0.001 & 0.451 & 0.615 & 0.469 \\
\hline I2b physical attributes & 0.466 & 0.076 & 0.145 & 0.308 & 0.509 & 0.926 & 0.196 \\
\hline I2c legal matters & 0.016 & 0.027 & 0.354 & 0.357 & 0.317 & 0.500 & 0.283 \\
\hline I2d lease details & 0.438 & 0.132 & 0.425 & 0.011 & 0.171 & 0.037 & 0.055 \\
\hline I2e purchase cost & 0.473 & 0.098 & 0.001 & 0.282 & 0.205 & 0.398 & 0.581 \\
\hline I2f CMV & 0.193 & 0.034 & 0.012 & 0.477 & 0.316 & 0.956 & 0.864 \\
\hline I2g OPEX & 0.106 & 0.687 & 0.125 & 0.597 & 0.320 & 0.139 & 0.149 \\
\hline I2h maintenance & 0.419 & 0.728 & 0.129 & 0.445 & 0.549 & 0.465 & 0.848 \\
\hline I2I staff numbers & 0.635 & 0.645 & 0.014 & 0.493 & 0.429 & 0.110 & 0.036 \\
\hline I2j strategic use & 0.305 & 0.017 & 0.000 & 0.010 & 0.990 & 0.845 & 0.566 \\
\hline $\begin{array}{l}\text { I2k non-performing } \\
\text { Properties identified }\end{array}$ & 0.677 & 0.478 & 0.000 & 0.201 & 0.335 & 0.427 & 0.836 \\
\hline
\end{tabular}


Another interesting observation was that responses from those who felt CREAM did not need major improvement in their organisation were highly correlated with high levels of CRE MIS performance in the following areas: 
p.value

口 - current use of property

0.015

口 - physical attributes - i.e. size, dimensions, age etc

0.003

口 - legal matters including zoning, tenure etc

0.008

- - lease details if applicable

0.025

- purchase cost.

0.001

口 - operating/maintenance costs

0.048

口 - maintenance programme

0.037

Associations with the importance of CRE MIS were not significant for this group. In contrast, for those respondents who rated CRE MIS as important, the property issues rated as most important in their position were; benchmarking ( $p=0.023)$, contribution of cash flow from CRE ( $p=0.004)$, and developing strategy $(p=0.001)$. As would be expected, there was also a strong association between the importance of developing strategy and usefulness of the CRE MIS system in assisting strategic decision-making and identifying non-performing properties.

A similar pattern emerged in response to the question on time personally spent on activities. For respondents with high ratings for CRE MIS importance and CRE MIS performance there were significant positive associations with strategic level activities. See Table 4 for details

\section{Table 4 Associations Between Time Spent on Management Activities and CRE MIS}

\begin{tabular}{|c|c|c|c|c|c|c|c|c|c|c|c|c|c|c|c|}
\hline p values & 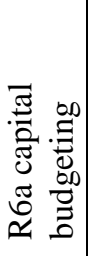 & 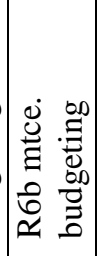 & 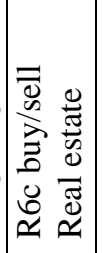 & 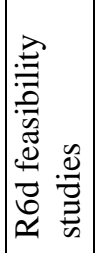 & 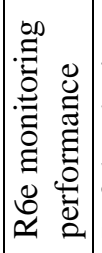 & 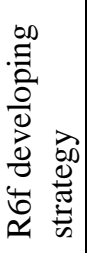 & 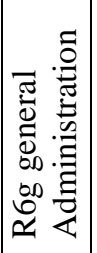 & 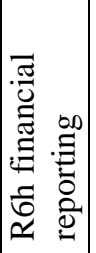 & 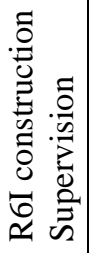 & 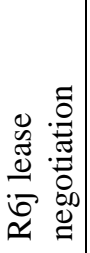 & 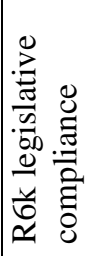 & 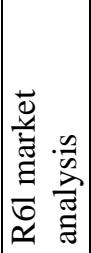 & $\begin{array}{ll}\tilde{n} & \\
0 & \\
0 & 0 \\
\Xi & 0 \\
0 & 0 \\
0 & 0 \\
\sim & 0\end{array}$ & 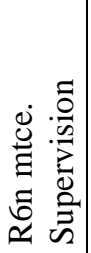 & 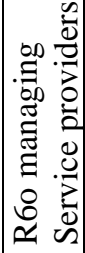 \\
\hline I1a MIS importance & 0.010 & 0.420 & 0.000 & 0.039 & 0.025 & 0.000 & 0.335 & 0.775 & 0.014 & 0.000 & 0.035 & 0.010 & 0.282 & 0.492 & 0.001 \\
\hline I1b MIS performance & 0.002 & 0.449 & 0.009 & 0.070 & 0.007 & 0.000 & 0.778 & 0.501 & 0.310 & 0.026 & 0.032 & 0.131 & 0.236 & 0.219 & 0.156 \\
\hline I2a curre & 0.808 & 0.801 & 0.368 & 0.160 & 0.264 & 0.003 & 0.883 & 0.985 & 0.378 & 0.073 & 0.306 & 0.038 & 0.031 & 0.290 & 0.074 \\
\hline I2b physical attributes & 0.808 & 0.801 & 0.368 & 0.160 & 0.264 & 0.003 & 0.883 & 0.985 & 0.378 & 0.073 & 0.306 & 0.038 & 0.031 & 0.290 & 0.074 \\
\hline I2c legal matters & 0.232 & 0.266 & 0.189 & 0.574 & 0.511 & 0.070 & 0.198 & 0.147 & 0.180 & 0.313 & 0.232 & 0.035 & 0.070 & 0.342 & 0.069 \\
\hline I2d lease details & 0.714 & 0.374 & 0.438 & 0.560 & 0.490 & 0.278 & 0.314 & 0.947 & 0.395 & 0.000 & 0.088 & 0.027 & 0.556 & 0.119 & 0.005 \\
\hline I2e purchase cost & 0.386 & 0.719 & 0.792 & 0.340 & 0.430 & 0.389 & 0.350 & 0.024 & 0.771 & 0.769 & 0.328 & 0.037 & 0.080 & 0.199 & 0.306 \\
\hline I2f CMV & 0.155 & 0.110 & 0.333 & 0.865 & 0.107 & 0.059 & 0.233 & 0.378 & 0.446 & 0.781 & 0.138 & 0.069 & 0.043 & 0.691 & 0.054 \\
\hline I2g OPEX & 0.179 & 0.074 & 0.015 & 0.307 & 0.246 & 0.820 & 0.382 & 0.073 & 0.068 & 0.350 & 0.302 & 0.396 & 0.043 & 0.306 & 0.020 \\
\hline I2h maintenance & 0.013 & 0.014 & 0.173 & 0.368 & 0.480 & 0.841 & 0.112 & 0.061 & 0.019 & 0.229 & 0.032 & 0.442 & 0.310 & 0.057 & 0.031 \\
\hline I2I staff numbers & 0.93 & 0.475 & 0.002 & 0.840 & 0.597 & 0.899 & 0.996 & 0.312 & 0.020 & 0.486 & 0.384 & 0.782 & 0.198 & 0.021 & 0.141 \\
\hline I2j strategic use & 0.103 & 0.383 & 0.214 & 0.173 & 0.085 & 0.000 & 0.845 & 0.046 & 0.130 & 0.201 & 0.037 & 0.012 & 0.086 & 0.337 & 0.103 \\
\hline $\begin{array}{l}\text { I2k non-performing } \\
\text { Properties identified }\end{array}$ & 0.276 & 0.017 & 0.319 & 0.022 & 0.004 & 0.088 & 0.483 & \begin{tabular}{|l|}
0.042 \\
\end{tabular} & 0.211 & 0.255 & 0.161 & 0.000 & 0.023 & 0.022 & 0.147 \\
\hline
\end{tabular}


In light of the above it was not surprising that the question on the existence of a written strategic plan for real estate was very highly and positively correlated with responses for importance of and performance of CRE MIS ( $\mathrm{p}=\mathrm{f}$ or both $<0.000)$. Significant associations with strategic planning were also observed for data sub-components of the CRE MIS such as: showing details on current use ( $\mathrm{p}=<0.000$ ), lease details $(\mathrm{p}=0.046)$, usefulness for strategic decision-making $(\mathrm{p}=0.003)$ and identifying non-performing properties $(\mathrm{p}=0.013)$.

There was a very strong positive association between responses on the number of, or value/rental cost of properties in the CRE portfolio and the importance of CRE MIS. This applied equally to both leasehold and freehold portfolios ( $\mathrm{p}$ for all <0.004). In contrast, there was a marked difference in significance between those with leased and freehold portfolios in relation to the performance of CRE MIS and portfolio size. Large leased portfolios were very highly associated with high performance CRE MIS $(\mathrm{p}=$ 0.001), whereas the association for large freehold portfolios was less significant $(p=0.047)$.

Logically, there were significant associations between leasehold portfolios and high performance in the CRE MIS data sub-components of lease details and legal data. Similarly, freehold portfolios were associated with high performance in respect of data on purchase cost, current market value and maintenance programmes

In respect of outsourcing, there was a tendency for increased outsourcing of various services to be associated with higher levels of CRE MIS performance in the areas of recording physical attributes, legal and lease details, and operating expenses. Similarly, it was also observed that those organisations that tended to rate cost analysis prior to outsourcing as very important also operated CRE MIS that recorded a lot of detail.

\section{Conclusions}

Since the earlier research of Teoh (1992), there has been a very substantial improvement in the percentage of organisations in New Zealand that both recognise the importance of CRE MIS and have put in place such systems. However, many users are unsatisfied with the performance of their existing systems, and comments were added to some survey forms stating that until you have experience with several CRE MIS you are unable to recognise their individual limitations. 
While $10 \%$ of organisations still rated CRE MIS as unimportant, this attitude is associated with smaller organisations with relatively few, generally freehold properties, a small or non-existent CRE unit and no current CRE MIS.

Large organisations tended to recognise the importance of CRE MIS but there was a marked difference between those with predominantly freehold and those with leasehold portfolios in the assessment of their own CRE MIS performance (leasehold portfolios showing more significant association with high performance CRE MIS). This also reflects Nourse (1994) who found organizations who lease, rather than own, better link their property decisions to strategic needs.

The data sub-components with the best performance within CRE MIS tended to be those items held in common with investment real estate and reflecting accounting requirements, such as recording lease details, current use, physical attributes and legal data. These latter types of historic information were also found to be dominant in existing CRE MIS by Redman, Johnson and Tanner (1994), but data to aid future decision-making was lacking.

Similarly, the areas of relatively poor CRE MIS performance in this research were often related to strategic decision-making, for example, identifing non-performing properties. However, the minority of organisations who held good strategic data were also those strongly associated with high levels of overall CREAM performance.

It became apparent looking across the results as a whole, that there appeared to be a division between those organizations that use their CRE MIS in a more "basic" way, dealing mainly with operational level decisions, and those using it for more "advanced” strategic level decisions.

For example, those organizations that were more satisfied with the performance of their CRE MIS and did not rate it as very important, often also rated strategic activities and data as less important.

In contrast, those who rated the importance of CRE MIS highly were likely to spend more time on, and rate as more important, strategic level activities and data. They were also likely to use more sophisticated decision-making techniques and be more highly qualified. This group was also strongly and positively associated with other measures of CREAM performance. 
These differences in the degree to which organisations use their CRE MIS for strategic decisionmaking may be reflective of the five stage CREAM development process put forward by Joroff et al (1993), in that it is necessary to achieve a satisfactory level of performance at one stage of development before progress can be made at the next level. It could be that those organisations operating at the lower level "Taskmasters" and “Controller” stages may be quite happy with the particular output of a CRE MIS whereas the same data would be quite inadequate if they were operating at the highest "Business Strategist” level.

This means future development of CRE MIS systems may need to focus on identifying and integrating strategic level information, rather than operational data, so as to facilitate the movement of the organization to higher stages of development and therefore improved CREAM performance. This may prove difficult as strategic data varies more from organization to organization than operational data, and standard CRE MIS software packages, which are often based on accounting or investment property models, may have trouble coping.

There was also an association between restructuring of both the organisation as a whole, and restructuring of the CRE unit, and the importance of CRE MIS. It could be that, as reported by French(1994), restructuring is a catalyst for marked improvement in CRE MIS. Or, as Byrne (1994) found a "chicken and egg” type situation develops with the need to have a strategic corporate real estate plan "forcing” the development of an effective CRE MIS , or alternatively the output of an effective CRE MIS stimulating the development of a strategic corporate real estate plan.

In a similar way an improved CRE MIS in certain areas may be a catalyst or prerequisite for increased outsourcing. This is reflected by a significant association between high levels of performance in a number of CRE MIS sub-data components and increased outsourcing. There was also a negative association between increased outsourcing and number of CRE staff, which may indicate productivity gains.

However, improvements in CRE MIS are not a panacea for all CREAM problems. As higher stages of CREAM development and performance are achieved, more strategic level analysis and decisions will have to be made. These strategic level decisions are often characterized by less availability of hard data and established methodology than lower level decisions, and rely more on the experience, integrative and intuitive abilities of management. 
A good CRE MIS is a foundation, and nothing solid can be built without one. But a foundation is only part of a much bigger building.

\section{REFERENCES}

Apgar, M. (1993). Uncovering Your Hidden Occupancy Costs. Harvard Business Review, May-June 1993, 124-136. Avis, M., Gibson, V., \& Watts, J. (1989). Managing Operational Property Assets. Department of Land Management and Development, University of Reading 1989.

Bourne, J. (1988a). Estate Management in the National Health Service. National Audit Office (UK), March 1988.

Bourne, J. (1989). Home Office: Control and Management of the Metropolitan Police Estate. National Audit Office (UK), June 1989.

Byrne, P. (1994). The Review of Local Government - The Effects on the Management of Property Assets. Property Management, Vol. 12 No.3, 5-8.

French, N. (1994). Asset Registers and Asset Rents for Local Authorities. Property Management, Vol.12 No 3, 1523.

Gale, J., \& Case, F. (1989). A Study of Corporate Real Estate Resource Management. Journal of Real Estate Research, Vol.4 No. 3, fall 1989, 23-34.

Gibson, V., (1991). Private v Public: Who Manages Operational Property Most Effectively. Property Management (UK), Vol. 9 No. 1, 4-9.

Gibson, V. (1994). Strategic Property Management - How Can Local Authorities Develop a Property Strategy. Property Management (UK), Vol. 12 No. 3, 9-14.

Gibson, V. (1995a). Is Property on the Strategic Agenda. Property Review, May 1995, 104-109.

Gibson, V. (1995b). Managing in the Millennium. Estates Gazette, Issue 9518, 1995, 109- 112.

Johnston L.E, Redman, A.L., \& Tanner J.R. (1997). Utilization and Application of Business Computing Systems in Corporate Real Estate. Journal of Real Estate Research, Vol. 13 No. 4 , 211- 230.

Joroff, M., Louargand,M., Lambert,S,, \& Becker,F. (1993) Strategic Management of the Fifth Resource: Corporate Real Estate. International Development Research Foundation, Report No. 49. IDRC, Atlanta Georgia USA, 1993. Lundstrom, S. (1991). A Comparison Between Public and Private Real Estate Management. Working paper presented at American Real Estate Society conference Sarasota, Florida, 10-13 April 1991.

McDonagh, J.,\& Hayward, T. (2000). Outsourcing Corporate Real Estate Asset Management in New Zealand. Journal of Corporate Real Estate, Vol.2 No.4, 351-371.

McDonagh, J. (2001). Measuring Corporate Real Estate Asset Management Performance. Paper presented at the Seventh Pacific Rim Real Estate Society Conference, Christchurch, 21-23 January 2002.

Nourse, H.O. (1994). Measuring Business Real Property Performance. Journal of Real Estate Research, fall 1994, 431-443.

Pittman, R. H., \& Parker, J.R. (1989). A Survey of Corporate Real Estate Executives on Factors Influencing Corporate Real Estate Performance. Journal of Real Estate Research, Vol.4 No. 3, 107-119. 
Redman, A.L., Johnston L.E, \& Tanner J.R. (1994). The Use of Business Computing Systems in Corporate Real Estate. Corporate Real Estate Executive, September 1994, 32-35.

Royal Institution of Chartered Surveyors (RICS). (1997). The Property Management Practices of Local Authorities. Evidence to the Audit Commission (UK), Audit Commission 1987.

Silverman, R.A. (1990). Bricks Mortar and Assets. Keystone Advisers Inc. Cambridge, Massachusetts 1990.

Simons, R.A. (1993). Public Real Estate Management - Adapting Corporate Practice to the Public Sector. The Journal of Real Estate Research, fall 1993, 639-653.

Teoh, W. K. (1992). Corporate Real Estate Asset Management: The New Zealand Evidence. The Journal of Real

Estate Research, Vol. 8 No 4, 607 - 623.

Veale, P.R. (1988) Managing Corporate Real Estate Assets: A survey of US Real Estate Executives. MIT, Laboratory of Architecture and Planning, 1988.

Veale, P.R. (1989). Managing Corporate Real Estate Assets: Current Executive Attitudes and Prospects for an Emergent Discipline. Journal of Real Estate Research, Vol.4. No.3, fall 1989, 1-21.

Zeckhauser, S., \& Silverman, R. (1983). Rediscover Your Company's Real Estate. Harvard Business Review, Jan/Feb 1983, 111-117. 